\title{
The University of Massachusetts Medical School Child Trauma Training Center (UMMS-CTTC)
}

BACKGROUND: Research indicates that childhood trauma is a pervasive, global, healthcare crisis with a majority $(68 \%)$ of children having experienced exposure to traumatic events. ${ }^{1}$ Youth who have multiple exposures to violence or victimization are at higher risk for mental health problems, behavioral problems, substance abuse, and delinquent behaviors, often resulting in their involvement with the court system. ${ }^{2,3,4,5}$ The majority of children who experience traumatic events are seen first by their pediatricians, schools, or courts and law enforcement before being referred for trauma assessment/treatment. By training professionals in these groups, the University of Massachusetts Medical School Child Trauma Training Center (UMMS-CTTC) aims to identify and improve access for children who would benefit from evidence-based trauma-focused treatment, specifically, Trauma-Focused Cognitive-Behavioral Therapy (TF-CBT). ${ }^{6}$

MISSION: The UMMS Child Trauma Training Center mission is to improve the identification of trauma and increase trauma-sensitive care and access to evidence-based trauma-focused treatment for at-risk and underserved populations in Central and Western Massachusetts, including court-involved youth and military families, ages 6 to 18 years.

\begin{tabular}{|c|c|}
\hline Population Focus: & $\begin{array}{l}\text { - Children and adolescents ages 6-18 who have experienced trauma and reside } \\
\text { in Central and Western Massachusetts (Worcester and Hampden counties) }\end{array}$ \\
\hline $\begin{array}{l}\text { Specific Trainings } \\
\text { CTTC will provide: }\end{array}$ & $\begin{array}{l}\text { Trauma-informed, trauma-sensitive training for professionals (pediatricians, } \\
\text { court personnel, law enforcement, attorneys, schools) to assist in the } \\
\text { identification, screening, and/or assessment of trauma and trauma-related } \\
\text { symptoms } \\
\text { Training in Trauma-Focused Cognitive-Behavioral Therapy (TF-CBT), and } \\
\text { adaptations to TF-CBT for court-involved youth and youth of military families } \\
\text { Disaster response training } \\
\text { - Training on cultural competence and the treatment of trauma (e.g. trauma \& } \\
\text { Latino families) } \\
\text { Training on family engagement strategies with youth and families who have } \\
\text { experienced trauma }\end{array}$ \\
\hline Goals: & $\begin{array}{l}\text { - Provide training in trauma-sensitive care to } 1800 \text { professionals } \\
\text { - Create a centralized referral system inclusive of a network of mental health } \\
\text { agencies and practitioners trained in evidence-based trauma treatments, toll- } \\
\text { free number 1-855-LINK-KID } \\
\text { - Provide training in TF-CBT to increase number of clinicians trained in an } \\
\text { evidence-based trauma treatment } \\
\text { Provide trauma-focused treatment to } 900 \text { youth and their families in } 60 \text { cities } \\
\text { and towns in Central MA and } 23 \text { cities and towns in Western MA }\end{array}$ \\
\hline
\end{tabular}

RESEARCH TEAM: Jessica L. Griffin, PsyD (Principal Investigator); Melodie Wenz-Gross, PhD (Co-PI); Toni Irsfeld (Project Director); Heather Forkey, MD (Co-I); Thomas Grisso, PhD (Co-I); Laurel Post (Centralized Referral Coordinator) FUNDER: SAMHSA Grant\# S61110000021849; TIME FRAME: 2012-2016; CONTACT PERSON: Jessica.griffin@umassmed.edu

The Child Trauma Training Center, a program within the Department of Psychiatry, UMass Medical School/UMass Memorial Health Care, and the Center for Mental Health Services Research, is funded by a 4-year Substance Abuse Mental Health Services Administration (SAMHSA), National Child Traumatic Stress Network (NCTSN) Category III grant.

For more information: http://www.umassmed.edu/CTTC.aspx 
1. Copeland, W. E., Keeler, G., Angold, A., \& Costello, E. J. (2007). Traumatic events and posttraumatic stress in childhood. Archives of General Psychiatry, 64(5), 577-84. doi:10.1001/ archpsyc.64.5.577

2. Ford, J. D., Chapman, J. F., Hawke, J., \& Albert, D. (2007). Trauma Among Youth in the Juvenile Justice System: Critical Issues and New Directions. National Center for Mental Health and Juvenile Justice, (June).

3. Ford, J. D., Elhai, J. D., Connor, D. F., \& Frueh, B. C. (2010). Poly-victimization and risk of posttraumatic, depressive, and substance use disorders and involvement in delinquency in a national sample of adolescents. The Journal of Adolescent Health, 46(6), 545-52. doi:10.1016/j. jadohealth.2009.11.212

4. Saunders, B. E., Williams, L. M., Smith, D. W., \& Hanson, R. F. (2005). The Navy's future: Issues Related to Children Living in Families Reported to the Family Advocacy Program. Department of the Navy Family Advocacy Program.

5. Tuell, J. A. (2008). Child Welfare \& Juvenile Justice Systems Integration Initiative: A Promising Progress Report. Child Welfare League of America, Inc.

6. Cohen, J. A., Mannarino, A. P., \& Deblinger, E. (2006). Treating trauma and traumatic grief in children and adolescents (p. 256). The Guilford Press 